\title{
Sarmila Bose, Dead Reckoning: Memories of the 1971 Bangladesh War
} (NY: Columbia University Press, 2011), x + 239 pp., ISBN 978-0-231-70164-8, \$33.75.

\section{Tawfique al-Mubarak, IAIS Malaysia}

In 1971, by a devastating war, Bangladesh (then East Pakistan) achieved independence from (West) Pakistan. Since then, both parties have documented and presented their research findings on the war. However, many of these findings have lacked credibility. Perhaps the only objective account on the 1971 war has been Richard Sisson and Leo Rose's War and Secession: Pakistan, India and the Creation of Bangladesh (1991). Sarmila Bose's recent work, Dead Reckoning, today constitutes a significant contribution to the research on Bangladesh's war of independence, all the more so for its unique methodology in using multiple sources of original information and cross-checked eyewitness testimonies from all parties involved. Pakistani army personnel as well as Bangladeshi muktijoddhas (freedom fighters) and victims of the war were interviewed to authenticate currently available materials, many of which appear to have been exaggerated with the force of emotion. This distinguishes the work from many other books authored by proponents of either party to the conflict. This book is certainly an eye-opener for researchers on the 1971 war.

The book is divided into nine chapters, each referring to the approximate chronology of events from December 1970 until the end of the war in December 1971. Chapter one ("Call to Arms") describes the general election of 1970 and the victory of the Awami League (AL) led by Sheikh Mujibur Rahman with a majority of seats in the parliament. Bhutto, despite losing the election, aspired to be Prime Minister of all Pakistan, and hence refused to accept the negotiations mediated by Yahya Khan, who was then the President and Chief Martial Law Administrator of Pakistan. Sheikh Mujib, too, was adamant that he should become Prime Minister. The negotiations ended without fruitful results; thus Yahya announced the postponement of the national assembly. This immediately set off violent revolts by the Bengalis. Sheikh Mujib's speech on 7 March stopped just short of declaring independence; he was still negotiating with the expectation of becoming the Prime Minister.

The Bengalis' revolts spread throughout the state immediately after the announcement. The following chapter ("Military Inaction") describes how the control over East Pakistan weakened and shifted to a parallel government led by Sheikh Mujib, with no mutually agreed resolution to the conflict. In the Joydevpur incident of 19 March 1971, two Bengali citizens were killed in a shootout between civilians and the Pakistan army, exacerbating the tense situation between the two parts of Pakistan. 
Chapter three ("Military Action") describes "Operation Searchlight" conducted on the Dhaka University campus by the Pakistani government on the night of 25 March 1971, "a military solution, which ultimately proved to be catastrophic for Pakistan." The Pakistani army crushed the resistance of the students in the residential halls, and elsewhere in adjoining apartments of the faculty, innocent unarmed civilians were massacred.

Chapters 4-8 detail the brutal atrocities committed by both of the warring sides. "Uncivil War", the fourth chapter, illustrates through ten cases the bitter feud that festered during subsequent months, following the military action of $25 \mathrm{March}$. As the Pakistani army had killed innocent civilians and Bengali Hindus, the Bengalis also killed their Bihari brethren in East Pakistan. In Joydevpur and Gazipur, Bengali soldiers revolted against the non-Bengali and West Pakistani army personnel, killing West Pakistani officers and their families. In Khulna, at the People's Jute Mill, the Bengalis took up whatever weapons they found and attacked the Biharis, "killing everyone they could find - men, women and children." Similar incidents took place at Mymengsingh, Santahar and at Chittagong's Karnaphuli Mill. The Pakistan government's White Paper on the gruesome situation estimates that about 15,000 Biharis were killed. Chaos and bloodshed spread widely throughout the state during the earlier months after the military action.

Chapter 5 ("Village of Widows") describes the mass killing at Thanapara village in Rajshahi by the Pakistani army on 13 April 1971. Men were separated from women and children and brutally shot, their bodies stacked in a pile and set on fire. Bose writes with emotion that this was "one of the grisliest of stories I heard in the course of my study of the 1971 war!"

The chapter "Hounding of Hindus" describes how Hindus were murdered by the Pakistani army at Chuknagar, at the borders of Khulna and Jessore districts, while they were fleeing their homes because of looting and harassment, mostly by local Bengali Muslims. Questioning the popular Bengali narration that 10,000 people were murdered there, Bose considers it a figure "too large" that an army contingent of just three truck loads of soldiers could murderously dispatch within just a couple of hours that many people. The scepticism that Bose, a Hindu, here evinces suggests a concern for strict objectivity of analysis in her research into what was certainly a heinous crime.

The seventh chapter ("Hit and Run") provides documentation of instances in which underground Bengali guerrillas like Alvi and Rumi, having trained in India, demonstrated their dedication to an independent Bangladesh. The bestial killings of prominent Bengali scholars by the Al-Badr and Al-Shams groups at the Rayerbazar brick-kiln and other places are described in the eighth chapter ("Fratricide"). The muktijoddhas too, it must be said, similarly killed Bengali supporters of a united Pakistan in the most brutal manner. Bengalis killing other 
Bengalis for either supporting or opposing a united Pakistan became a regular occurrence during the last weeks of December 1971.

The last chapter ("Words and Numbers") addresses the myth underlying 'Sheikh Mujib's famous statement: "I discovered that they had killed three million of my people." Bose argues that so far no authentic references have substantiated the claim. She concludes that between 50,000 to 100,000 people perished in the war of 1971, including combatants and non-combatants, on both sides. Similarly, the often-cited figure of 93,000 Pakistani soldiers taken as POWs is also unrealistic, given a contingent which had a total of only 55,000 members in East Pakistan during the war, civilian officials and army personnel combined.

The fundamental contribution of the book is that it reveals how the whole discourse of liberation and separation has been sullied by fictions. Although the popular Bengali versions of the 1971 war describe the atrocities committed by the Pakistani army, rarely is mention made of Bengali attacks on Biharis and non-Bengalis.

Bose does not directly address the current situation in which political leaders are undergoing trials at the International Crimes Tribunal (ICT) in Bangladesh, but her descriptions suggest that these trials are largely driven by concocted discourses for political motives. The book is significant for employing a robust methodology to uncover the myths and realities surrounding the 1971 war, which Bose concludes left "a land of violence with a legacy of intolerance of difference and a tendency to respond to political opposition with intimidation, brutalization and extermination" for the next generation. 